\title{
The Mechanical Effect of Rod Contouring on Rod-Screw System Strength in Spine Fixation
}

\author{
Nihat Acar, M.D., ${ }^{1}$ Ahmet Karakasli, ${ }^{2}$ Ahmet A. Karaarslan, ${ }^{3}$ Mehmet Hilal Ozcanhan, Ph.D., ${ }^{4}$ Fatih Ertem, M.S., ${ }^{5}$ Mehmet Erduran, M.D. ${ }^{2}$ \\ Department of Orthopaedics and Traumatology, ${ }^{1}$ Ilyas Cokay Catalca Hospital, Catalca, Istanbul, Turkey \\ Department of Orthopaedics and Traumatology, ${ }^{2}$ Faculty of Medicine, Dokuz Eylul University, Balcova, Izmir, Turkey \\ Department of Orthopedics and Traumatology, ${ }^{3}$ Sifa Hospital, Konak, Izmir, Turkey \\ Department of Computer Engineering, ${ }^{4}$ Faculty of Engineering, Dokuz Eylul University, Tinaztepe, Izmir, Turkey \\ Department of Biomechanics, ${ }^{5}$ Health Science Institute, Dokuz Eylul University, Balcova, Izmir, Turkey
}

\begin{abstract}
Objective : Rod-screw fixation systems are widely used for spinal instrumentation. Although many biomechanical studies on rod-screw systems have been carried out, but the effects of rod contouring on the construct strength is still not very well defined in the literature. This work examines the mechanical impact of straight, $20^{\circ} \mathrm{kyphotic}$, and $20^{\circ}$ lordotic rod contouring on rod-screw fixation systems, by forming a corpectomy model.

Methods : The corpectomy groups were prepared using ultra-high molecular weight polyethylene samples. Non-destructive loads were applied during flexion/extension and torsion testing. Spine-loading conditions were simulated by load subjections of $100 \mathrm{~N}$ with a velocity of $5 \mathrm{~mm}$ min ${ }^{-1}$, to ensure 8.4-Nm moment. For torsional loading, the corpectomy models were subjected to rotational displacement of $0.5^{\circ} \mathrm{s}^{-1}$ to an end point of $5.0^{\circ}$, in a torsion testing machine.

Results : Under both flexion and extension loading conditions the stiffness values for the lordotic rod-screw system were the highest. Under torsional loading conditions, the lordotic rod-screw system exhibited the highest torsional rigidity.

Conclusion : We concluded that the lordotic rod-screw system was the most rigid among the systems tested and the risk of rod and screw failure is much higher in the kyphotic rod-screw systems. Further biomechanical studies should be attempted to compare between different rod kyphotic angles to minimize the kyphotic rod failure rate and to offer a more stable and rigid rod-screw construct models for surgical application in the kyphotic vertebrae.
\end{abstract}

Key Words : Biomechanics $\cdot$ Rod contouring $\cdot$ Rod failure.

\section{INTRODUCTION}

The rod-screw based systems are now considered the gold standard systems for spinal fixation. Transpedicular screw fixation, which are considered excellent stabilizer for spine segments, has been used frequently in the management of many spinal disorders, including degenerative diseases, fractures, tumors, scoliosis and deformities through the posterior approach ${ }^{12,14,22)}$. These rigid rod-screw systems facilitate reduction and manipulation of many deformities via rod preoperative and in situ bending, rotation, distraction and compression. The primary target of rod-screw system fixation is to prevent instability till biological arthrodesis occur ${ }^{11,22)}$. Rod-screw system failure through screw pullout, screw breakage and rod breakage are frequently encountered during clinical practice. Although many biomechanical studies on transpedicular screw pullout and breakage have been performed $^{1,2,8,10,17,22)}$, but it is strange that, the literature is lacking of a well-structured biomechanical study enriching the knowledge regarding the effect of rod contouring (lordotic and kyphotic curvatures) on the strength of the rod-screw construct and the impact of such different curvatures on rod fatigue and then breakage. The aim of the present biomechanical work is to study the behavior of different rod curvatures against variable stresses to detect the effect of rod contouring (straight, kyphotic and lordotic) on rod fatigue which leads later on to breakage.

\section{MATERIALS AND METHODS}

\section{Material model}

The well-known ultra-high molecular-weight polyethylene

- Received : February 13, 2016 • Revised : May 6, 2016 •Accepted : June 8, 2016

- Address for reprints : Nihat Acar, M.D.

Department of Orthopaedics and Traumatology, Ilyas Cokay Catalca Hospital, Catalca, Istanbul 34540, Turkey

Tel : +90-5375552636, Fax : +90-2012 78923 71, E-mail : zenanacar@gmail.com

- This is an Open Access article distributed under the terms of the Creative Commons Attribution Non-Commercial License (http://creativecommons.org/licenses/by-nc/3.0) which permits unrestricted non-commercial use, distribution, and reproduction in any medium, provided the original work is properly cited. 


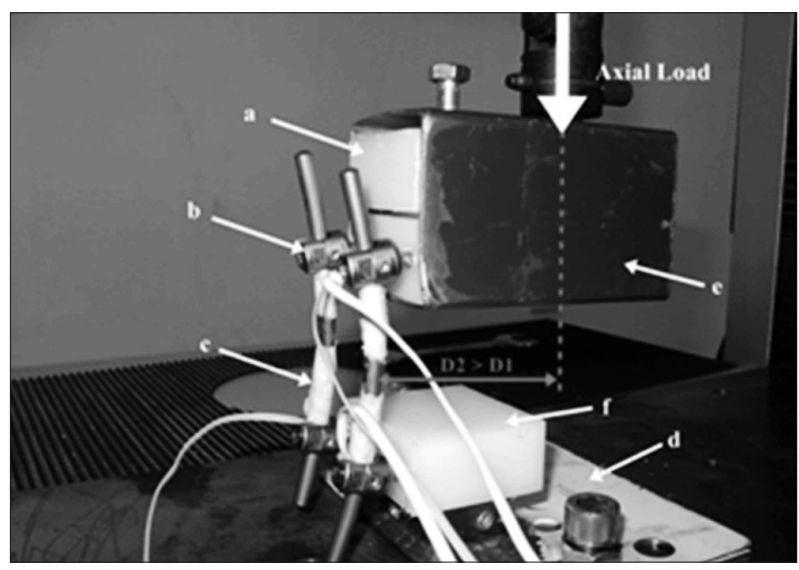

Fig. 1. Rod-screw system used in the corpectomy model. Universal test machine used for flexion/extension and deformation testing. a-f : UHMWPE blocks, b : poly-axial screws, c : strain-gauge, d-e : fixation apparatus.

(UHMWPE) samples were used to form three spine corpectomy model groups. UHMWPE blocks were preferred to be used in place of human bone, to avoid the biological differences of bone density. Many studies have reported the ability of using UHMWPE blocks to imitate corpectomy models as an approved method for mechanical evaluation of rod-screw systems stability ${ }^{20)}$.

Eighteen corpectomy models were created to simulate a human spine model (Fig. 1). Three types of rod models were used : straight $(n=6), 20^{\circ}$ kyphotic $(n=6)$, and $20^{\circ}$ lordotic $(n=6)^{5)}$.

\section{Instrumentation}

In our study, $45 \mathrm{~mm}$ long poly-axial titanium, $5.5 \mathrm{~mm}$ thick pedicle screws and $110 \mathrm{~mm}$ long titanium rods $(6.35 \mathrm{~mm}$ thick, TiAlV) (Tipsan Medical Devices, Izmir, Turkey) were used. The two titanium rods were attached and secured to the poly-axial screws (Fig. 1). A fixed longitudinal gauge with a $76 \mathrm{~mm}$ of length was present between the vertebrae block models, flexion/ extension and torsion apparatus was designed for simulating the corpectomy model ${ }^{20,22)}$. During our study, transverse connectors were not used, because earlier biomechanical studies have shown that transverse connectors do not effect compressive loading in mechanical tests ${ }^{8)}$. The titanium rods in the corpectomy models were fitted with a strain-gauge (UFLK-2-11 type, $120 \Omega$, $2 \mathrm{~mm}$ long, Tokyo Sokki Kenkyujo, Japan) placed in the middle and on each one's longitudinal axis. Another set of strain-gauges were placed at the heads of the pedicle screws and the strain at the screw heads was measured, according to the method previously described in the literature ${ }^{12,17,20)}$.

The flexion loading of the lordotic and kyphotic rod-screw systems (Fig. 2) shows that, the anterior bending moment applied on the lordotic rod-screw systems is $\mathrm{T} 1=\mathrm{F} 1 \times \mathrm{D} 1$; while the bending moment applied on the kyphotic rod-screw systems is $\mathrm{T} 2=\mathrm{F} 1 \times \mathrm{D} 2$. Although the same force F1 is applied to both systems, because of the distance from the center, the resultant bending moment $\mathrm{T} 2$ of the kyphotic rod-screw system is larger than T1 of the lordotic system, as D2>D1.

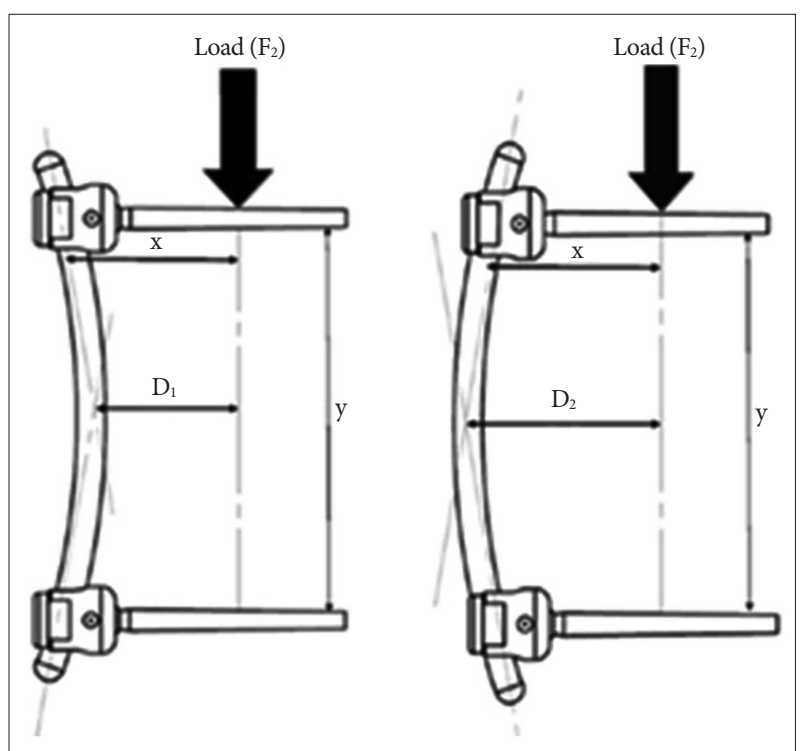

Fig. 2. Schematic illustration of the lordotic and kyphotic rod-screw systems. $D_{1}$ and $D_{2}$ show the difference of the moment arm; $D_{2}>D_{1}$.

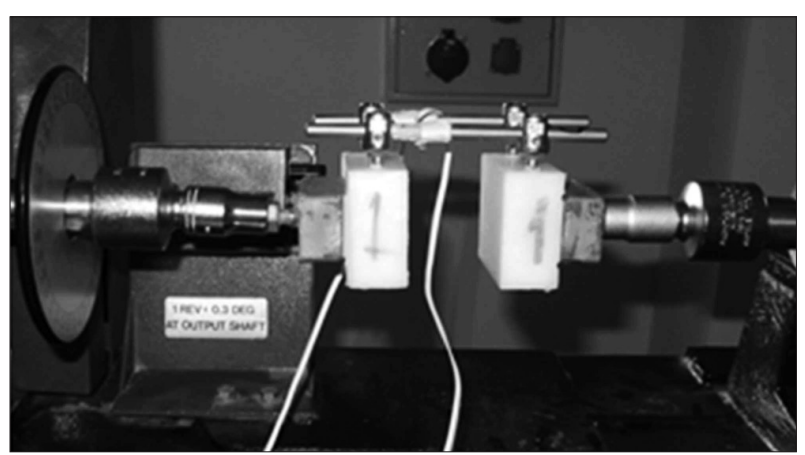

Fig. 3. A corpectomy model in the torsion testing machine.

\section{Mechanical testing}

The theoretical model of mechanical testing was accomplished using the well-known guidelines of ASTM F1717-04 "Static and Dynamic Test Method for Spinal Implant Assemblies in a Corpectomy Model" to evaluate the mechanical properties of the 6.5 $\mathrm{mm}$ rod under static and dynamic loading. Non-destructive load was applied during flexion/extension and torsion testing ${ }^{9,20,22)}$. In order to apply the load to the corpectomy models, a custommade system was designed for the test machines. Flexion/extension tests were accomplished using an electromechanical universal testing machine (Shimadzu 5kN AG-X, Japan) (Fig. 1). To simulate spine-loading conditions, the samples were subjected to a load of $100 \mathrm{~N}$ to ensure an 8.4-Nm moment with a velocity of $5 \mathrm{~mm} \mathrm{~min}^{-1}{ }^{7,22)}$ To examine torsional loading, the UHMWPE blocks were mounted in a torsion testing machine (TecQuipment, Ltd., United Kingdom) and subjected to rotational displacement of $0.5^{\circ} \mathrm{s}^{-1}$ to an end point of $5.0^{\circ}$ (Fig. 3) ${ }^{19,20)}$. The obtained data were analyzed using SPSS v.15. for Windows (SPSS Inc., Chicago, IL, USA). The non-parametric one-way analysis of variance was used for categorical comparisons. Sta- 
tistical significance level was set at $p<0.05$.

\section{RESULTS}

Stiffness was recorded in all rod systems during application of deformation loads, lordotic rods had a mean stiffness value of $22.98 \mathrm{~N} \mathrm{~mm}^{-1}$, versus $12.82 \mathrm{~N} \mathrm{~mm}^{-1}$ for the straight rods. Statistical significance was detected between the mean stiffness values of both rod systems with $p=0.001$. The straight rods mean stiffness value was $44.2 \%$ less than that of the lordotic rods. The mean stiffness for the kyphotic rods was $17.19 \mathrm{~N} \mathrm{~mm}^{-1}$. Statistical significance was detected between the mean stiffness values of both rod systems with $p=0.007$. The kyphotic rods mean stiffness values was $25.1 \%$ less than that of the lordotic rods. Statistical significance was detected between the mean stiffness values of the kyphotic rods and the straight rods with $p=0.02$. The straight rods mean stiffness value was $25.4 \%$ less than that of the kyphotic rods (Fig. 4).

Under extension conditions, the mean strain values for straight, kyphotic and lordotic rods were $(1086 \mu \varepsilon, 1244 \mu \varepsilon, 1124 \mu \varepsilon)$ respectively. Statistical significance was detected between the mean strain value of the kyphotic rods when compared to the straight and lordotic rods with $p$ values of (0.006 and 0.004$)$ respectively (Fig. 5).

Whereas the mean strain values measured from the heads of

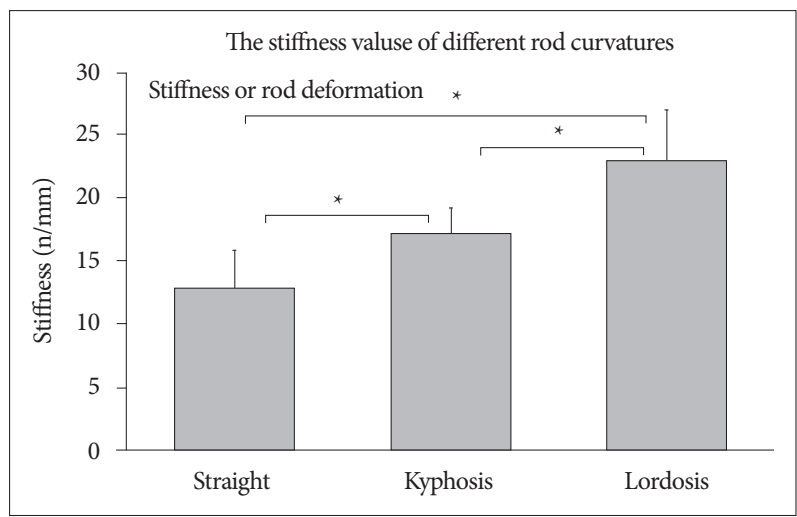

Fig. 4. The stiffness values of different rod models.

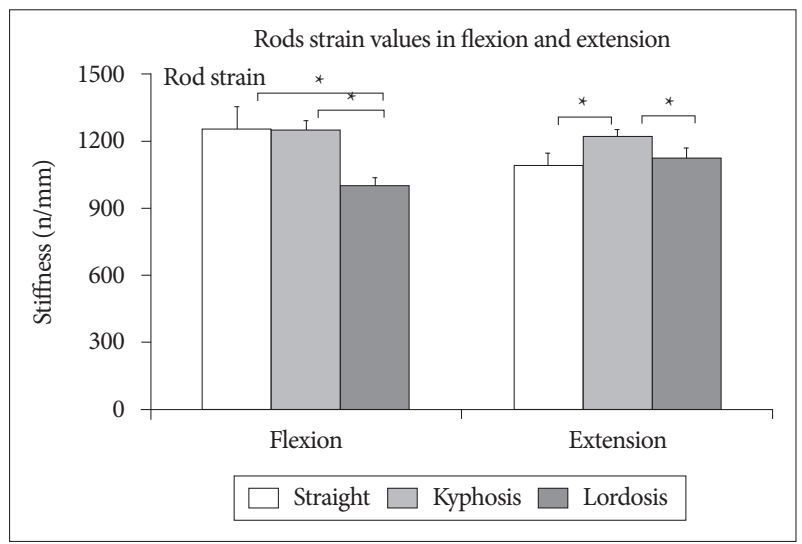

Fig. 5. Rod strain values during flexion and extension. polyaxial screws in extension of the straight, kyphotic and lordotic rod-screw systems were $(37 \mu \varepsilon, 23 \mu \varepsilon, 26 \mu \varepsilon)$ respectively. Straight screw heads show the highest strain values during extension which is statistically significant when compared to kyphotic and lordotic heads with $p$ values of $(0.004,0.006)$ respectively (Fig. 6).

Under flexion conditions, the mean strain values for straight, kyphosis and lordotic rods were $(1249 \mu \varepsilon, 1244 \mu \varepsilon, 1001 \mu \varepsilon)$ respectively. Statistical significance was detected between the mean strain value of the lordotic rods when compared to the kyphotic and straight rods with $p$ values of $(0.004$ and 0.003$)$ respectively. No statistical significance was detected between the kyphotic rods and the straight rods with a $p$ value of 0.873 .

Whereas the mean strain values measured from the heads of polyaxial screws in flexion of the straight, kyphotic and lordotic rod-screw systems were $(18 \mu \varepsilon, 33 \mu \varepsilon, 31 \mu \varepsilon)$ respectively. Straight screw heads demonstrate the lowest strain values during flexion, the difference is statistically significant when compared to kyphotic and lordotic heads with $p$ values of $(0.004,0.006)$ respectively.

Under torsional conditions, the mean stiffness values for straight, kyphotic and lordotic rods were (2.55 Nm degree ${ }^{-1}, 3.05$ $\mathrm{Nm}_{\text {degree }} \mathrm{e}^{-1}, 3.25 \mathrm{Nm}_{\text {degree }}{ }^{-1}$ ) respectively. Statistical significance was detected between the mean stiffness value of the straight rods when compared to that of the lordotic and kyphotic rods

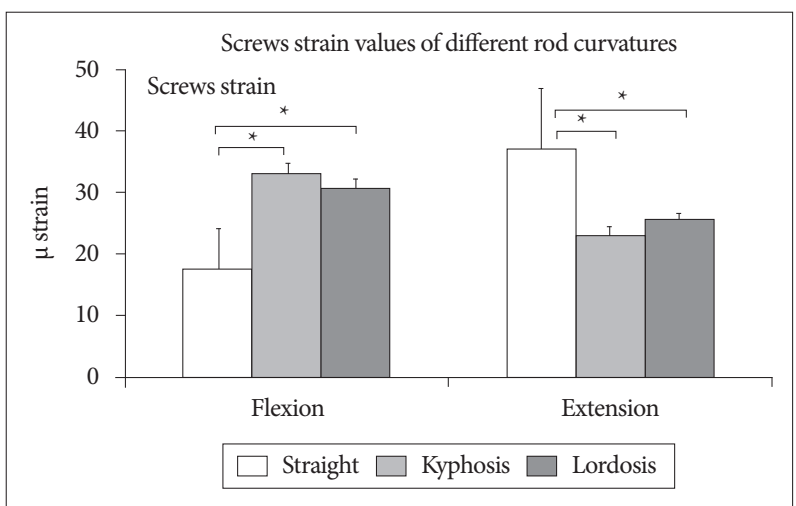

Fig. 6. Screws strain values of different rod curvatures during flexion and extension.

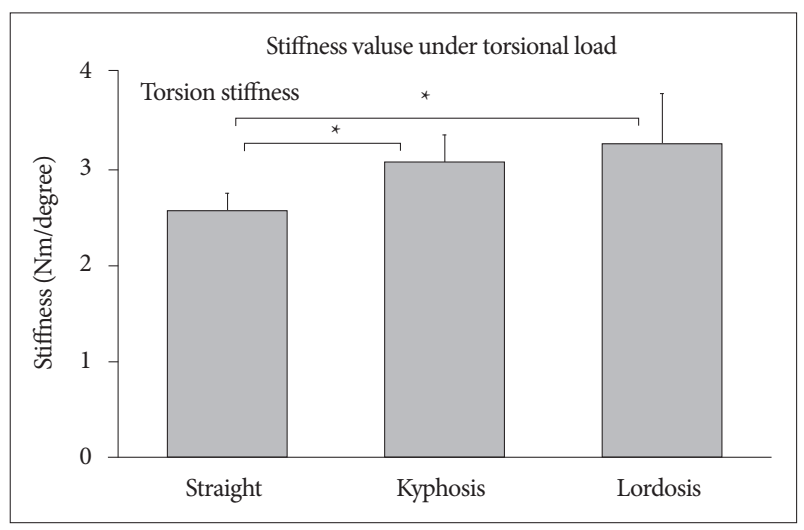

Fig. 7. Rod-screw systems stiffness values under torsional load. 
with $p$ values of $(0.025,0.013)$ respectively. No statistical significance was detected between the kyphotic and the lordotic rods in torsional conditions with $p$ value of 0.38 (Fig. 7).

\section{DISCUSSION}

Many studies in the literature had documented that the strength of rod-screw system was mostly associated to the structural anatomic relationship between the size of the isthmus of the pedicle and the rod-screw diameter ${ }^{9,21,22)}$. The created model of corpectomy is considered as an extremely aggressive surgical scenario, due to the fact that, all loads are transmitted from the healthy segment proximally to the distal one completely through the rod-screw system ${ }^{12)}$.

Many studies have used UHMWPE model as a corpectomy model. The model attempts to eliminate the variable biological differences of human vertebrae samples like size, bone density and shape $\mathrm{e}^{22)}$. Clinically the yield strength of a rod-screw system is more relevant than that of the ultimate strength. One of the main aims of any fixation system is to preserve the stability mainly in the sagittal plane. As it has been defined before, if the axial compressive loads exceed the yield strength of a system, an implant permanent deformation is likely to occur, resulting in a kyphotic deformity. Exceeding the implant ultimate strength is problematic and demonstrates a bad surgical application due to support absence of the spine anterior column. Any rod-screw system is designed to create stability in the spine during the healing period of bone grafting must be resistant to fatigue failure. It is estimated that 1 million cycles (approximately 4 months) is enough for fusion to take place ${ }^{17,19,22)}$. The aim of our study is twofold; to detect the impact of rod curves on rod failure and to record the effect of such curves on the stress created upon the screw heads which leads to screw failure in the future.

The highest level of stiffness was observed in the lordotic rodscrew system. It was significantly higher than that of the straight rod-screw system $(p=0.002)$ and that of the kyphotic rod system ( $p=0.004$ ), indicating that the lordotic rod-screw system is the most stable and rigid system under static conditions without dynamic loading.

Under flexion conditions, lordotic rods show the least mean strain values when compared to that of the straight rods and that of the kyphotic rods with a significant statistical difference of $p$ values (0.004 and 0.003$)$ respectively. No statistical significance was detected between the kyphotic rods and the straight rods with $p=0.873$. This indicates that, lordotic rods are more resistant to flexion loadings when compared to straight and kyphotic rods.

Under flexion loading, the highest polyaxial screw head strain was observed in the kyphotic rod-screw system (33 $\mu \varepsilon)$ (Fig. 3). The strain on the screw heads of the straight rod-screw system was statistically lower than that of the kyphotic and lordotic rodscrew systems with $p$ values of $(0.004,0.006)$ respectively. Based on these findings, we think that, screw failure especially in the kyphotic rod-screw system under flexion loading is more likely to occur. Chen et al., showed that pedicle screws commonly broke/fractured at the junction of the screw and the UHMWPE blocks ${ }^{4,8)}$. Schroerlucke et al. ${ }^{15)}$, showed that implant failure is more common in patients with increased kyphosis and increases with a line parallel to the degree of kyphosis. Rod failure is the most common rod-screw implant complication.

Under extension loading rod strain gauge measurements were $1244 \mu \varepsilon$ in the kyphotic rods. Under extension loading, the strain of the kyphotic rod-screw system was significantly higher than that of the straight and lordotic rod-screw systems with $p$ values of $(0.006,0.004)$ respectively. These findings show that the straight rod-screw system was the most rigid system under extension loading. Sun at al. ${ }^{18)}$, showed that, supporting the pedicle screw with an infra-laminar hook enhances the stiffness of a construct by $21 \%$ in kyphosis. In thoracolumbar fusion surgery with rod-screw systems, failure rates ranged from $0.4 \%$ to $22 \%$. In situ rod contouring and corrective surgeries using devices for reduction are considered as risk factor for the failure of pure titanium or titanium alloy made spinal constructs; due to their bending sensitivity ${ }^{6,13,16)}$. In rod-screw systems, if the mechanical properties of rod contouring are known, it may guide the surgeons to make a better choice for a more stable rod-screw constructs.

Under extension loading conditions, the strain occurring in the pedicle screw heads was measured. The highest screw strain $(37 \mu \varepsilon)$ was recorded for the straight rod-screw system, as compared to the lordotic rod-screw system $(26 \mu \varepsilon)$ and kyphotic rodscrew system $(23 \mu \varepsilon)$. It is thought that the likelihood of screw failure is high in the straight rod-screw system under extension loading.

In an artificial spine model, Belmont et al. ${ }^{3)}$, demonstrated that, as kyphotic angle increased up to $27^{\circ}$, the strain of the rod increased by $27 \%$. Our results are in line, because the mean kyphotic rod strain was $1244 \mu$ and the mean lordotic rod strain was $1001 \mu$. The mean lordotic rod strain value was significantly lower than the strains in straight and kyphotic rod-screw systems ( $p=0.003$ and $p=0.004$ ) respectively. Based on the strain values, the lordotic rod-screw system was the most rigid of the 3 systems, under flexion loading. This is expected, because $\mathrm{D}_{2}$ is greater than $D_{1}$, as demonstrated in Fig. 2. Because of spine's natural shape, the application of kyphotic spine implants have larger bending distances than lordotic spine implants, i.e., $\mathrm{D}_{2}>\mathrm{D}_{1}$.

Under torsional loading conditions the lordotic rods system in the present study exhibited the greatest rotational rigidity (3.24 Nm degrees ${ }^{-1}$ ), followed by the kyphotic rod-screw and the straight rod-screw systems. Which show statistical significance with $p$ values of (0.013 and 0.025$)$ respectively (Fig. 4). The lordotic rod-screw system was the most rigid system of the 3 systems examined in the present study.

This study contains some limitations which can not be avoided like many other in-vitro biomechanical studies and this is due to the difficulty in resambeling the physiological conditions 
of a human spine without muscles and soft tissue which is wellknown to increases the construct rigidity and the stability of the bone-implant interface.

\section{CONCLUSION}

In extension loading, the lordotic rod-screw system exhibited the greatest stiffness and rigidity. Also in rotational loading, the lordotic rod-screw system exhibited the greatest rotational rigidity. Under flexion loading, the highest mean strain value was observed in the straight rod-screw and the lowest was in the lordotic rod-screw system. These findings show that, the lordotic rod-screw system was the most rigid of the 3 systems tested. The polyaxial screw strain in extension was higher in the straight rod-screw system and lower in the kyphotic rod-screw system, whereas in flexion loading of the polyaxial screw, the highest strain was recorded in the straight and kyphotic rodscrew systems and the lowest strain was recorded in the lordotic rod-screw system.

This study shows that, failure may take place in the kyphotic portion of the rod-screw system, additionally the polyaxial screws in the kyphotic segment of the rod-screw systems are in a higher risk of failure when compared to other curves. Further biomechanical studies should be attempted to compare between different rod kyphotic angles to minimize the kyphotic rod failure rate and to offer a special designs for the kyphotic screws and rods to create a more stable rod-screw construct models for surgical application in the kyphotic vertebrae.

\section{References}

1. Alkalay RN, Sharpe D, Bader DL : A biomechanical analysis of an instrumented spinal fixator under torsional loads. J Biomech 38 : 865 876, 2005

2. Baaj AA, Reyes PM, Yaqoobi AS, Uribe JS, Vale FL, Theodore N, et al. : Biomechanical advantage of the index-level pedicle screw in unstable thoracolumbar junction fractures. J Neurosurg Spine 14 : 192-197, 2011

3. Belmont PJ Jr, Polly DW Jr, Cunningham BW, Klemme WR : The effects of hook pattern and kyphotic angulation on mechanical strength and apical rod strain in a long-segment posterior construct using a synthetic model. Spine (Phila Pa 1976) $26: 627-635,2001$

4. Chen PQ, Lin SJ, Wu SS, So H : Mechanical performance of the new posterior spinal implant : effect of materials, connecting plate, and pedicle screw design. Spine (Phila Pa 1976) 28 : 881-886, 2003

5. Chen WJ, Lai PL, Tai CL, Chen LH, Niu CC : The effect of sagittal alignment on adjacent joint mobility after lumbar instrumentation--a biomechanical study of lumbar vertebrae in a porcine model. Clin Biomech (Bristol, Avon) 19 : 763-768, 2004

6. Gilad R, Gandhi CD, Arginteanu MS, Moore FM, Steinberger A, Camins $\mathrm{M}$ : Uncorrected sagittal plane imbalance predisposes to symptomatic instrumentation failure. Spine J 8 : 911-917, 2008

7. Karakaşlı A, Sekik E, Karaarslan A, Kızmazoğlu C, Havıtçığlu H : Are pedicular screws and lateral hook screws more resistant against pullout than conventional spinal hooks and screws in terminal vertebral segment fixation? Eklem Hastalik Cerrahisi 27 : 22-28, 2016

8. Kim H, Lim DH, Oh HJ, Lee KY, Lee SJ : Effects of nonlinearity in the materials used for the semi-rigid pedicle screw systems on biomechanical behaviors of the lumbar spine after surgery. Biomed Mater 6 : 055005, 2011

9. Kotani Y, Cunningham BW, Parker LM, Kanayama M, McAfee PC : Static and fatigue biomechanical properties of anterior thoracolumbar instrumentation systems. A synthetic testing model. Spine (Phila Pa 1976) 24 : 1406-1413, 1999

10. Lehman RA Jr, Polly DW Jr, Kuklo TR, Cunningham B, Kirk KL, Belmont PJ Jr : Straight-forward versus anatomic trajectory technique of thoracic pedicle screw fixation : a biomechanical analysis. Spine (Phila Pa 1976) 28 : 2058-2065, 2003

11. Liu T, Zheng WJ, Li CQ, Liu GD, Zhou Y : Design and biomechanical study of a modified pedicle screw. Chin J Traumatol 13 : 222-228, 2010

12. Mikles MR, Asghar FA, Frankenburg EP, Scott DS, Graziano GP : Biomechanical study of lumbar pedicle screws in a corpectomy model assessing significance of screw height. J Spinal Disord Tech 17 : 272-276, 2004

13. Okamoto T, Neo M, Fujibayashi S, Ito H, Takemoto M, Nakamura T : Mechanical implant failure in posterior cervical spine fusion. Eur Spine J $21:$ 328-334, 2012

14. Ponnappan RK, Serhan H, Zarda B, Patel R, Albert T, Vaccaro AR : Biomechanical evaluation and comparison of polyetheretherketone rod system to traditional titanium rod fixation. Spine J 9 : 263-267, 2009

15. Schroerlucke SR, Akbarnia BA, Pawelek JB, Salari P, Mundis GM Jr, Yazici M, et al. : How does thoracic kyphosis affect patient outcomes in growing rod surgery? Spine (Phila Pa 1976) 37 : 1303-1309, 2012

16. Smith JS, Shaffrey CI, Ames CP, Demakakos J, Fu KM, Keshavarzi S, et al. : Assessment of symptomatic rod fracture after posterior instrumented fusion for adult spinal deformity. Neurosurgery $71: 862-867,2012$

17. Stanford RE, Loefler AH, Stanford PM, Walsh WR : Multiaxial pedicle screw designs : static and dynamic mechanical testing. Spine (Phila Pa 1976) $29: 367-375,2004$

18. Sun E, Alkalay R, Vader D, Snyder BD : Preventing distal pullout of posterior spine instrumentation in thoracic hyperkyphosis : a biomechanical analysis. J Spinal Disord Tech $22: 270-277,2009$

19. Villa T, La Barbera L, Galbusera F : Comparative analysis of international standards for the fatigue testing of posterior spinal fixation systems. Spine J 14 : 695-704, 2014

20. Wahba GM, Bhatia N, Bui CN, Lee KH, Lee TQ : Biomechanical evaluation of short-segment posterior instrumentation with and without crosslinks in a human cadaveric unstable thoracolumbar burst fracture model. Spine (Phila Pa 1976) 35 : 278-285, 2010

21. Wang XY, Dai LY, Xu HZ, Chi YL : Biomechanical effect of the extent of vertebral body fracture on the thoracolumbar spine with pedicle screw fixation : an in vitro study. J Clin Neurosci 15 : 286-290, 2008

22. Xu HZ, Wang XY, Chi YL, Zhu QA, Lin Y, Huang QS, et al. : Biomechanical evaluation of a dynamic pedicle screw fixation device. Clin Biomech (Bristol, Avon) 21 : 330-336, 2006 